\title{
PEMANFAATAN INTERNET SEHAT MENUJU KEHIDUPAN BERKEMAJUAN
}

\author{
Doni Winarso*, Syahril, Aryanto, Edo Arribe, Risnal Diansyah \\ Prodi Sistem Informasi, Fakultas Ilmu Komputer \\ Universitas Muhammadiyah Riau \\ *Email :doniwinarso@umri.ac.id
}

\begin{abstract}
Abstrak
Perkembangan teknologi internet membawa perubahan yang sangat besar terhadap kehidupan manusia disegala bidang. Ibarat pisau bermata dua, di satu sisi internet bisa digunakan untuk kegiatan positif dan di sisi lainnya internet dapat merusak tatanan kehidupan bermasyarakat jika digunakan untuk hal-hal yang negatif. Pemanfaatan internet sehat tentunya bisa membuat kehidupan lebih berkemajuan, hal ini disebabkan banyaknya informasi dan pengetahuan bisa diambil oleh pengguna dari situs-situs yang ada di internet. Tantangan tersendiri terkait perkembangan internet adalah pada generasi muda terutama yang berada di tingkat SMA. Sehingga diperlukan cara untuk mengedukasi mereka agar dapat menggunakan fasilitas yang ada di internet untuk tujuan yang positif. Guru sebagai pendidik tentunya dapat menjadi fasilitator untuk mengarahkan peserta didiknya dalam penggunaan internet sehat. Tujuan dari pengabdian kepada masyarakat ini adalah untuk memberikan edukasi kepada para guru di lingkungan SMA Negeri 9 Pekanbaru dalam hal pemanfaatan internet menuju kehidupan yang berkemajuan. Dengan adanya edukasi ini diharapkan dapat menjadi tongkat estafet dalam membantu mengarahkan para siswa berkaitan dengan penggunaan internet yang positif.
\end{abstract}

Kata kunci: Berkemajuan, Internet, SMAN 9 Pekanbaru

\section{PENDAHULUAN}

Teknologi informasi saat ini sudah menjadi sebuah kebutuhan yang sangat berarti di berbagai sendi kehidupan [1]. Bahkan teknologi informasi telah berhasil mengubah beberapa cara seseorang maupun organisasi dalam menjalankan aktivitas sehari-harinya, terlebih setelah terbukanya jaringan global dunia yang menghubungkan antar sebuah komputer dengan komputer lainnya atau disebut dengan internet. Jaringan ini telah sukses mengubah cara berkomunikasi, cara mengekspresikan diri, atau mengubah cara memasarkan sebuah produk dalam dunia perdagangan.
Bahkan perubahan besar terjadi di ranah pendidikan yang diakibatkan oleh perkembangan teknologi.

Dunia pendidikan sebagai pusat berkembangnya Ilmu Pengetahuan dan Teknologi (IPTEK) dan penghasil Sumber Daya Manusia (SDM) yang berkualitas tentulah sangat menyambut baik kehadiran teknologi informasi yang semakin canggih [2]. Namun kendala yang dihadapi adalah masih belum dapat mengoptimalkan ketersediaan fasilitas dan teknologi yang ada karena kurangnya keterampilan dan pengetahuan tentang aplikasi internet. Selanjutnya merupakan tantangan tersendiri terkait perkembangan internet adalah pada 
ISSN : 2550-0198

generasi muda terutama yang berada di tingkat SMA. Sehingga diperlukan cara untuk mengedukasi mereka agar dapat menggunakan fasilitas yang ada di internet untuk tujuan yang positif.

Guru memiliki peran sebagai sebagai pendidik, dan menggantikan peran orang tua ketika siswa sedang berada di sekolah. Peran tersebut semestinya dapat menjadikan guru sebagai fasilitator untuk mengarahkan peserta didiknya dalam penggunaan internet sehat. Tentunya untuk menjadi fasilitator penggunaan internet sehat mengharuskan seorang guru untuk dapat memiliki pengetahuan tentang bagaimana internet sehat, sehingga nantinya guru menjadi tongkat estafet dalam membantu mengarahkan siswa untuk dapat menggunakan internet dengan baik dan sehat.

Pentingnya peran guru utuk dapat mendidik para siswa terutama pada tingkat SMA dalam penggunaan internet secara positif ditangkap dan diterjemahkan ke dalam bentuk pengabdian dengan tema pemanfaatan internet sehat menuju kehidupan berkemajuan yang diselenggarakan di SMA Negeri 9 Pekanbaru.

\section{METODE PENGABDIAN}

Kegiatan ini dilaksanakan di SMA Negeri 9 Pekanbaru pada Bulan Maret 2017. Peserta yang terlibat sebanyak 35 orang yang merupakan majelis guru di lingkungan SMA Negeri 9 Pekanbaru.

Metode kegiatan pengabdian dilakukan dengan ceramah, praktik dan diskusi. Kegiatan tersebut dapat dilihat pada table berikut ini:
Tabel 1. Pelaksanaan Kegiatan

\begin{tabular}{|c|c|c|}
\hline No & Kegiatan & ateri \\
\hline 1 & $\begin{array}{l}\text { Pengenalan } \\
\text { Internet }\end{array}$ & $\begin{array}{l}\text { - Pengantar } \\
\text { internet } \\
\text { - Sejarah dan } \\
\text { perkembangan } \\
\text { internet } \\
\text { - Fasilitas yang } \\
\text { ada diintenet }\end{array}$ \\
\hline 2 & Media Sosial & $\begin{array}{l}\text { - Facebook } \\
\text { - Instagram } \\
\text { - Twiter } \\
\text { - Googleplus } \\
\text { - YouTube }\end{array}$ \\
\hline 3 & $\begin{array}{l}\text { Dampak } \\
\text { Perkembangan } \\
\text { Internet }\end{array}$ & $\begin{array}{l}\text { - Sisi Positif dan } \\
\text { Negatif Internet }\end{array}$ \\
\hline 4 & $\begin{array}{l}\text { Pemanfaatan } \\
\text { internet untuk } \\
\text { kehidupan } \\
\text { berkemajuan }\end{array}$ & $\begin{array}{l}\text { - Isu terkait } \\
\text { penggunaan } \\
\text { internet (hukum, } \\
\text { sosial) } \\
\text { - Penggunaan } \\
\text { internet positif } \\
\text { - Kebaikan } \\
\text { internet sekarang } \\
\text { dan masa yang } \\
\text { akan datang. }\end{array}$ \\
\hline
\end{tabular}

Instrumen yang digunakan selama kegiatan berlangsung adalah, infocus yang digunakan untuk menampilkan slide presentasi, laptop, jaringan internet, situs media sosial. Pada kegiatan ini juga ditampilkan sebuah sistem informasi yang digunakan untuk membuat raport siswa secara online.

\section{HASIL DAN PEMBAHASAN}

Upaya pengabdian kepada masyarakat yang telah dilakukan berupa seminar dan workshop dengan berbagai materi khususnya menyangkut penggunaan internet sehat. Semua kegiatan berjalan sesuai dengan jadwal acara yang telah disusun sebelumnya. 
Program pengabdian masyarakat berjudul "Pelatihan Internet Sehat Menuju Kehidupan Berkemajuan di SMAN 9 Pekanbaru" yang awalnya direncanakan sebanyak 65 orang, namun karena kegiatan beriringan dengan jam sekolah sehingga kegiatan ini hanya dihadiri oleh 34 orang guru SMAN 9 Pekanbaru. (Daftar Hadir Terlampir)

Internet mempunyai peran yang besar dalam pembelajaran, yaitu sebagai salah satu referensi ilmu pengetahuan, alat manajemen pengetahuan, jaringan pakar beragam ilmu, jaringan antar institusi pendidikan, pusat pengembangan materi ajar, wahana pengembangan kurikulum, dan komunitas perbandingan standar kompetensi [2]. Internet merupakan sebuah jaringan komunikasi tanpa batas yang melibatkan jutaan komputer pribadi (Personal Komputer) yang tersebar di seluruh dunia. Dengan menggunakan Transmision Control Protocol (TCP) dan didukung dengan media komunikasi seperti satelit, telefon, dan paket radio, internet memungkinkan terjadinya komunikasi antar komputer dengan jarak yang tidak terbatas.

Jaringan internet memungkinkan untuk melakukan konferensi dari beberapa orang yang letaknya berjauhan. Mereka yang hadir dalam konferensi tersebut cukup menghadap ke layar komputer dan mereka dapat melakukan interaksi satu sama lain [3]. Menurut Tabratas jaringan komputer dibagi dalam 3 jenis yaitu LAN (Local Area Network), MAN (Metropolitan Area Network dan WAN (Wide Area Networks) [4]. Internet merupakan salah satu kelompok jaringan komputer berdasarkan cakupan (jarak) dimana internet merupakan gabungan dari beberapa WAN di planet bumi ini sehingga menghasilkan suatu jaringan komputer global yang dinamakan internet.

\section{Sosial Media}

Dewasa ini komunikasi antar individu telah bermetamorfosis seiring dengan perkembangan teknologi informasi dan komunikasi. Diantara teknologi yang memiliki pengaruh besar adalah sosial media. Dibandingkan pengguna sosial media dunia, Indonesia menempati urutan ke 4 dalam penggunaan facebook, peringkat ke 5 pengguna twitter. Jumlah pengguna facebook sekitar 65 juta jiwa, 19,5 juta jiwa pengguna twitter, 700 ribu pengguna path, dan line 10 juta pengguna, google +3.4 juta pengguna serta 1 juta pengguna linkledin [5].

Salah satu media sosial yang popular yaitu facebook. Sosial media ini memiliki 17 tujuan bagi para penggunanya [6], tujuan ini dapat dilihat pada gambar berikut

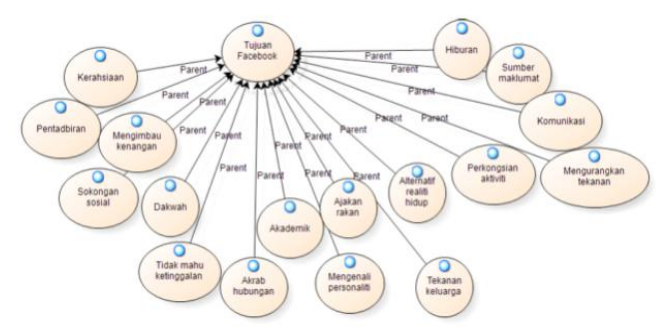

Gambar 1.Tujuan penggunaan facebook

Dari gambar di atas, salah satu tujuan penggunaan facebook adalah di bidang akademik. Facebook dapat digunakan untuk aktivitas akademik berupa pembuatan grup atau kelompok belajar virtual melalui dunia maya. Dari 10 siswa dan 
majelis guru di SMP Negeri 9 Pekanbaru, ketika ditanya tentang kepemilikan akun facebook, maka semua menyatakan memiliki akun facebook atau $100 \%$ menggunakan media sosial facebook.

Kegiatan pengabdian ini dilakukan dengan mengambil narasumber yang merupakan dosen dari Prodi Sistem Informasi Fakultas Ilmu Komputer Universitas Muhammadiyah Riau (UMRI). Pada sesi pertama pengenalan internet dipresentasikan oleh Doni Winarso, M.Kom yang dilanjutkan dengan pemaparan mengenai media sosial oleh Syahril, M.Kom. kegiatan dilanjutkan dengan penjelasan dampak penggunaan internet oleh Edo Arribe, MMSI, dan pemanfaatan internet sehat untuk kehidupan berkemajuan oleh Risnal Diansyah, MTI.

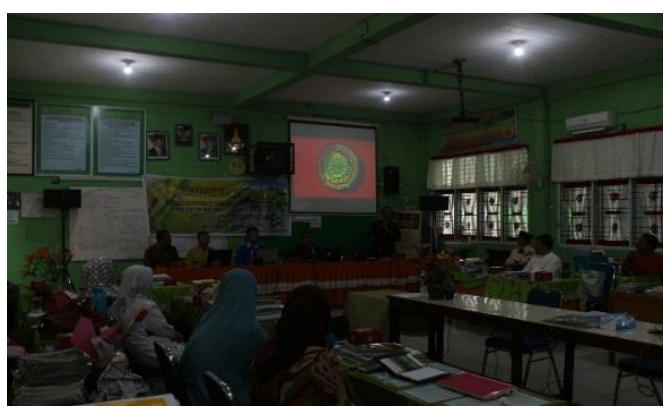

Gambar 2. Pemamparan Pengenalan Internet

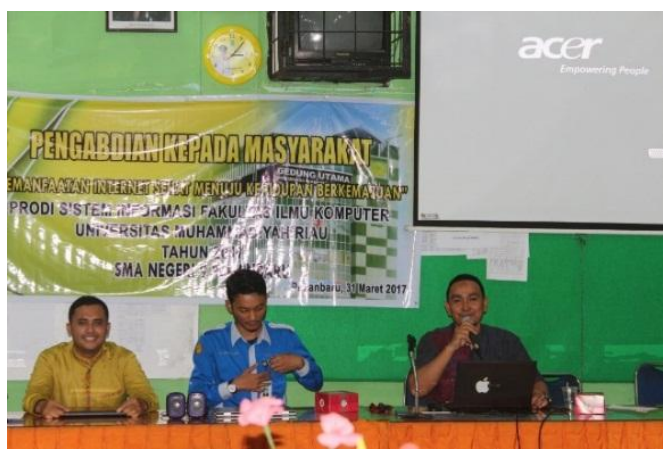

Gambar 3. Pemamparan Sosial Media

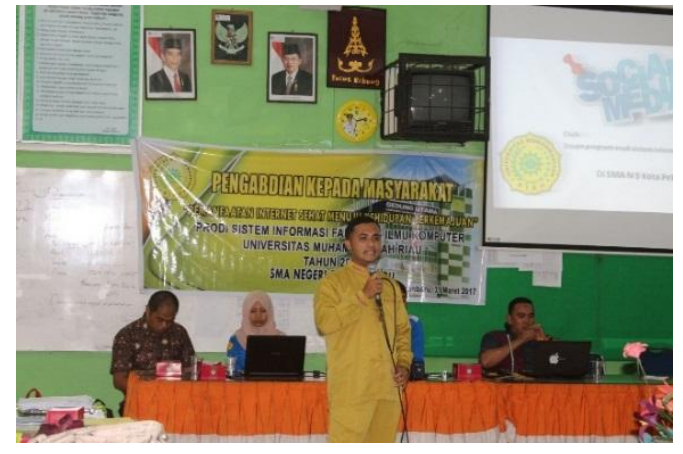

Gambar 4. Presentasi Pemanfaatan internet sehat untuk kehidupan berkemajuan

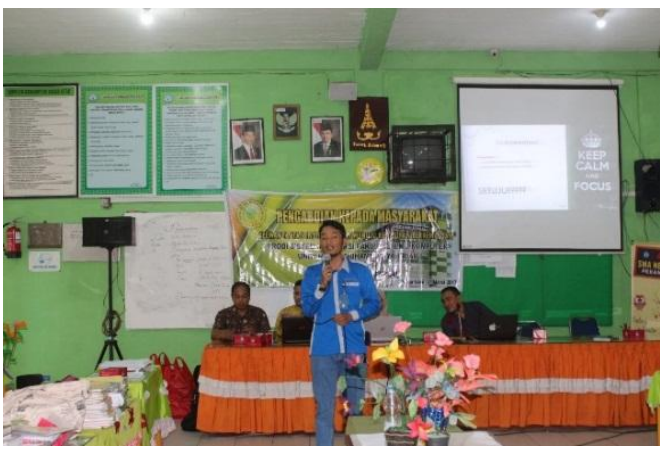

Gambar 5. Dampak Penggunaan Internet

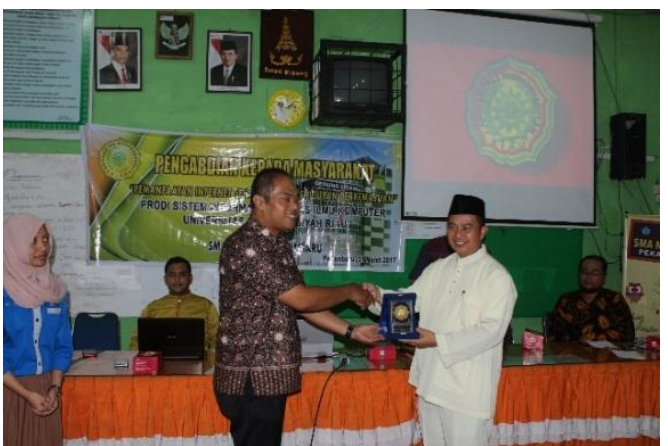

Gambar 6. Penyerahan Cindra Mata Kepada WAKA bidang Kurikulum

\section{SIMPULAN}

Dari kegiatan pengabdian yang telah dilakukan di SMA Negeri 9 Pekanbaru, dihasilkan bahwa para majelis guru memegang peran penting dalam mengarahkan siswa untuk dapat menggunakan internet sehat. Untuk itu diperlukan 
pengetahuan tentang bagaimana menggunakan internet sehat.

Dari kegiatan dan diskusi yang dilakukan, diambil kesimpulan:

Kegiatan seminar dan pelatihan diperlukan bagi para majelis guru di SMA Negeri 9 Pekanbaru. Hal ini karena rata-rata guru merupakan generasi yang kurang mengenal penggunaan internet.

Internet dapat menjadi sarana pembelajaran baik bagi guru maupun bagi para siswa.

Pemanfaatan internet sehat bagi para siswa dapat dipantau jika guruguru mengetahui dampak positif dan negatif yang ditimbulkan oleh internet. Hal ini karena sistem yang ada di SMA Negeri 9 Pekanbaru mengadopsi full day school, sehingga siswa bisa lebih lama mengikuti proses belajar mengajar di sekolah dibandingkan di rumah mereka.

\section{UCAPAN TERIMA KASIH}

Ucapan terima kasih disampaikan kepada:

1. Lembaga Penelitian dan Pengabdian Masyarakat (LPPM ) Universitas Muhammadiyah Riau (UMRI) yang telah memberikan dukungan berupa biaya dan motivasi.

2. HIMA Prodi Sistem Informasi yang telah membantu kegiatan pengabdian ini

3. SMA Negeri 9 Pekanbaru yang telah memfasilitasi kegiatan ini

4. Seluruh Peserta kegiatan yang merupakan para majelis guru dilingkungan SMA Negeri 9

Pekanbaru yang begitu antusias dalam mengikuti kegiatan ini.

\section{DAFTAR PUSTAKA}

[1] A. Nugroho, E-Commerce Memahami Perdagangan Modern di Dunia Maya. BANDUNG: Informatika, 2006.

[2] I. S. Huzni, "Pemanfaatan Media Internet Ssebagai Sumber Beajar," J. Iqra, vol. 2, pp. 72-83, 2008.

[3] B. S. D. Oetomo, CRM Membina Relasi Dengan Pelanggan. Yogyakarta: Penerbit Andi, 2003.

[4] T. Tharom, Mengenal Teknologi Informasi. Jakarta: Elex Media Komputindo Kelompok Gramedia, 2002.

[5] Depkominfo, "https:// kominfo.go .id/index.php /content/detail/3415/Kominfo $+\% 3 \mathrm{~A}+$ Pengguna+Internet+di +Indonesia+63+Juta+Orang/0/ berita_satker diakses tanggal 2 April 2017.".

[6] Che Su Binti Mustaffa and Nan Zakiah Megat Ibrahim, "Persepsi Dan Penggunaan Media Sosial Dari Perspektif Ibu Bapa: Satu Analisis Perception and the Use of Social Media From the Perspectives of Parents : a," J. Komun. Malaysia, vol. 30, pp. 43-74,2014. 